\title{
PAMĚŤOVÝ TEST UČENÍ Recenze metody
}

\author{
AUTOR RECEnZE: JOLANA STEHLÍKOVÁ1 \\ Katedra psychologie, Fakulta sociálních studií, Masarykova univerzita
}

\begin{tabular}{|c|l|}
\hline datum vzniku recenze: & 1.3. 2018 \\
\hline 1.1 název nástroje: & Pamět’ový test učení \\
\hline zkrácený název: & PTU \\
\hline 1.2 původní název: & The Rey Auditory-Verbal Learning Test \\
\hline 1.4 autoři původního testu: & A. Rey \\
\hline 1.3 autoři lokální adaptace: & M. Preiss \\
\hline 1.7 lokální distributor: & Psychodiagnostika, a.s., Psychiatrické centrum Praha \\
\hline $1.9 .1 / 1.9 .2$ datum vydání: & 1998, 1999, 2013 \\
\hline
\end{tabular}

\section{Obecné informace o metodě}

Pamět'ový test učení (PTU) představuje metodu určenou k měření paměti, zejména bezprostřední a krátkodobé verbální paměti. Ta se v testu projevuje množstvím zapamatovaných slov ze dvou sad (A a B). PTU obsahuje 2 sady slov po 15 slovech; první sada (A) je čtena pětkrát a po každém přečtení má respondent za úkol vyjmenovat co nejvíce zapamatovaných slov ve volném pořadí. Poté následuje druhá sada (B) a její vybavení a následně je proband požádán opětovně si vybavit co nejvíce slov ze sady A. Po 30 minutách následuje oddálené vybavení sady A, poté rekognice v podobě seznamu slov ze sad A a B a jejich fonetických a sémantických asociací, u nichž má proband vždy říci, zda se slovo nacházelo v sadě $\mathrm{A}$.

Metoda měří hned několik dílčích aspektů paměti. Předně jde o bezprostřední a krátkodobou verbální pamět', vybavování slov ihned po jejich přečtení administrátorem, vybavování po distrakci, oddálené vybavení, rekognici slov a v neposlední řadě metoda zkoumá proces učení. Test také sleduje míru opakování slov (kolikrát si respondent

\footnotetext{
${ }^{1}$ Masarykova univerzita, Fakulta sociálních studií, Katedra psychologie; Joštova 10, 60200 Brno. 
vybaví jednotlivá slova) a výskyt konfabulací (kolik vybavených slov nepatří mezi danou sadu A nebo B).

Test je dle manuálu možné využít $\mathrm{v}$ mnoha kontextech. Je vhodný pro rutinní psychodiagnostiku v poradenství, klinickou psychologii a pro posudkovou činnost. Diagnostikuje organické oslabení CNS, poruchy učení u dětí a demenci u dospělých (zvláště její počáteční formy). Jeho aplikace je doporučovaná i pro sledování následků úrazu hlavy a při diferenciální diagnostice poruch paměti (organické vs. funkční poruchy paměti).

\section{Vznik české verze}

Původní verze testu, Rey-Auditory-Verbal Learning Test (RAVLT) od Švýcara A. Reye, pochází z roku 1958. Samotné české vydání (Preiss, 1994) vychází částečně ze švýcarského originálu a jeho americké adaptace a je doplněno novými slovy. Preiss deklaruje „zachování smyslu slov a prezentování všeobecně známých, spíše krátkých a srozumitelných slov“ (s. 259, 1994), nicméně neuvádí, jakým způsobem onen překlad probíhal, kolik lidí se na něm podílelo apod.

Česká adaptace ${ }^{2}$ se liší od anglického originálu - srovnání prezentuje např. Bezdicek a kol. (2014). Tyto změny autoři (mj. včetně M. Preisse, autora české adaptace PTU) argumentují lepší kulturní ekvivalencí. Např. zatímco $v$ anglické verzi jsou šesté a deváté slovo listu A v jednotném čísle, v české verzi (listy A CZ a B CZ) je překlad v čísle množném. Obdobně pak patnácté slovo listu A, označující v českém prostředí neexistující povolání, je nahrazeno jiným, avšak v česku běžným povoláním. Dvanácté slovo listu A odkazuje jak ke konkrétnímu státu, tak k názvu jídla. V české adaptaci je proto použit jiný stát, který je však zároveň homonymem s označením jiného jídla.

Český respondent má rovněž za úkol zapamatovat si celkově větší množství slabik než anglicky mluvící, a to 9-10 slabik na sadu, a zároveň v anglické adaptaci jsou slova maximálně dvojslabičná, zatímco v české verzi jsou i tříslabičná a jedno čtyřslabičné, což může zapamatování ztížit. Na druhou stranu jsou to slova, která jsou v našem jazyce běžně používaná, takže respondenti je dobře znají (Bezdicek et al., 2014).

\section{Předpoklady použití}

Dle manuálu má administraci a vyhodnocování provádět psycholog dopředu seznámený s manuálem. Autoři nekladou další explicitní požadavky na uživatele metody.

Předpoklady použití metody související s respondenty jsou kromě pochopitelných prvků, jako jasnost vědomí, klidné prostředí, ostrost sluchu (případně funkční naslouchátko u lidí s problémy se sluchem), omezeny pouze věkem, resp. existujícími normami.

\section{Administrace a skórování}

2 Z důvodu ochrany podnětového materiálu uvádíme jen pořadí slov a příslušný list; vlastník testu si může konkrétní př́klady dohledat sám. 
Čas potřebný $\mathrm{k}$ administraci testu je $\mathrm{v}$ manuálu odhadnutý na 10 minut, nicméně test nemá žádný omezený čas, jelikož se čeká, dokud respondent neřekne, že už si nic nevybavuje. Seznámení se s testem je (pro administrátora) velmi jednoduché a časově nenáročné. Samotná administrace neklade žádné zvláštní nároky, pouze (poměrně samozřejmé) velmi pečlivé obeznámení se s jednotlivými slovy, aby je administrátor přečetl jasně a srozumitelně a byl schopen je zaznamenat a při interpretaci rozeznat dle jejich prvních slabik, jelikož první vybavená slova respondenta přichází většinou najednou ve větší skupině, kde z časových důvodů nelze zapisovat celá slova (pokud se nejedná o konfabulace), aby se zajistilo správné zaznamenání všech slov, která si respondent vybaví. PTU je možno administrovat bud' individuálně, nebo skupinově s tím, že ve skupině probandi zapisují sami vybavená slova a administrátor následně vyplní jejich záznamové archy. Autoři neuvádějí, jaký je vliv různého způsobu administrace na výsledky v testu.

Pořizovací náklady na test činí 2439 Kč bez DPH a v ceně je zahrnuta příručka pro práci s testem a 200 záznamových archů pro děti a 200 pro dospělé.

Získané hodnoty lze interpretovat na celkem 8 škálách. Vybavení 1-5 je 5 součtů slov, které si proband vybaví ihned po přečtení sady slov. Počet opakování slov vyjadřuje součet všech slov, která si proband vybaví $2 \mathrm{x}$ a vícekrát v jednom pokusu vybavování. Počet konfabulací představuje počet vybavených slov, která nepatří do dané sady slov. Opakování i konfabulace se zapisují jak pro jednotlivé pokusy, tak v celkovém počtu za prvních pět pokusů. Celkový výkon je součtem všech správně vybavených položek z prvních pěti pokusů. Výkon v sadě B ukazuje počet vybavených slov z distrakční sady B a zároveň stálost výkonu probanda (v porovnání s prvním pokusem sady A). Vybavení sady A po distrakci sadou B značí počet správně vybavených položek ze sady A po sadě B. Oddálené vybavení sady A ukazuje počet vybavených slov ze sady A po 30 minutách. Rekognice značí počet správně označených slov patřících do sady A při expozici distraktorů v podobě sady $\mathrm{B}$ a fonetických nebo sémantických asociací sad A a B.

Interpretace výsledků probíhá na základě hrubých skórů získaných ve výše popsaných škálách, neprovádí se transformace na standardní skóry, nicméně ve většině orientačních norem jsou k dispozici průměry a směrodatné odchylky, takže transformace skórů možná je, pokud to povaha vyšetření vyžaduje.

\section{Manuály}

Manuál k PTU je dostupný ve třech formách. První manuál vydaný v roce 1998 společností Psychodiagnostika a.s. (Preiss, 1998) a druhý vydaný v roce 1999 tamtéž (Preiss, 1999) se od sebe liší pouze mírně. Největší rozdíl mezi nimi je absence orientačních norem pro dospělé v manuálu z roku 1998.

Test je také včetně manuálu a norem dostupný v knize Neuropsychologická baterie Psychiatrického centra Praha (Preiss, Bartoš, \& Čermáková, 2013), spolu s dalšími testy jako ACE-R, Trail making test apod. $V$ této knize je méně prostoru věnováno vývoji 
českých norem a psychometrickým charakteristikám, nicméně jsou zde některé novější zahraniční (orientační) normy pro dospělé.

\section{Normy}

Normy, ze kterých vychází české vydání PTU, byly vytvořeny na standardizačním vzorku 182 dětí (102 chlapců a 80 dívek) z různých pražských ZŠ ve věku 9-14 let. V každém věkovém pásmu bylo vyšetřeno 30 dětí kromě jedenáctiletých $(\mathrm{N}=32)$. Normy jsou rozděleny zvlášt' pro dívky a chlapce po jednotlivých rocích. Autor nijak nevysvětluje důvody pro rozdělení norem po letech a pohlaví, nicméně ve shrnutí výsledků uvádí, že dívky mají vyšší skóre opakování a jsou lepší než chlapci v celkovém počtu vybavených slov, a pamět'ový výkon u dětí s věkem vzrůstá od 9 do přibližně 12 let. Dále autor doporučuje výsledky brát spíše informativně, jelikož všechny děti ze studie pochází z Prahy a oproti běžné populaci bylo ve vzorku jejich rodičů $3 x$ častěji zastoupeno vysokoškolské vzdělání. Preiss a kolegové provedli v roce 2001 rozšíření této studie na vzorek 550 dětí (Preiss, Motejlková, Janů, \& Kolárová, 2001).

Pro adolescenty a dospělé jsou normy v manuálu pouze orientační, jelikož jsou převzaty ze zahraničních studií. Zde je velká paleta různě věkově odstupňovaných norem až do 87 let, pro muže a ženy zvlášt' i dohromady, pro zdravou populaci i specifické populace pacientů. Za nejkvalitnější autor považuje meta-analýzu osmi studií z let 1980-2003, provedenou na 1910 zdravých osobách ve věku 20-79 let (Mitrushina, Boone, Razani, \& D‘Elia, 2005), publikovanou v manuálu z roku 2013. Autor nepopisuje žádný postup jak vybrat nejkvalitnější orientační normu; je zde tedy ponechán prostor úsudku administrátora testu.

Ačkoliv normy pro dospělé jsou pouze orientační, M. Preiss píše, že výsledky české populace v PTU jsou téměř shodné s americkými i švýcarskými normami, což ukazuje na studii žáků středních škol, a tedy orientační normy lze brát poměrně vážně.

Oproti manuálu byla v roce 2014 vydaná česká studie reportující normy pro zdravou populaci mezi 20 a 85 lety (Bezdicek et al., 2014). Autoři (mimo jiné i M. Preiss, autor PTU) studii prováděli na 306 respondentech (182 žen, 124 mužů) a zahrnuli do analýzy všech 8 aspektů PTU i vliv věku, pohlaví a délky studia.

\section{Validita}

Popisu validity, resp. jejích důkazů, není v manuálu věnováno mnoho pozornosti. Pokud jde o konstruktovou validitu, důkazy se omezují na korelaci výkonu v PTU s věkem a s IQ. Na vzorku psychiatrických pacientů $(\mathrm{N}=47)$ byla zjištěna korelace $-0,37$ mezi věkem a celkovým výkonem v testu (na 5\% hladině významnosti). Čím vyšší byl věk participantů, tím horší byl výkon $v$ testu. U dětí (N=182) s rostoucím věkem v pásmu 9-14 let naopak pamět'ový výkon vzrůstal $(\mathrm{r}=0,34)$, mezi 12.-14. rokem však již jen minimálně. Počet opakování s věkem klesal $(\mathrm{r}=-0,16)$, ale počet konfabulací nikoliv $(\mathrm{r}=0,02)$. Tyto výsledky odpovídají teoretickým informacím o paměti, jelikož výsledky v pamět'ových testech by se v dětství měly zlepšovat, $\mathrm{v}$ dospělosti být poměrně ustálené a ve stáří se opět zhoršovat. 
Korelace s inteligencí jsou v dětském souboru nízké, pro celkové IQ 0,21, pro verbální i názorové 0,18 . Tuto skutečnost lze chápat jako důkaz o divergentní validitě. Jinak řečeno, na základě hodnot korelací lze říci, že PTU měří něco jiného než inteligenci.

Popis konvergentní validity chybí úplně, stejně tak popis prediktivní validity a dalších aspektů validity.

Zároveň je nutno dodat, že zahraniční literatura tuto část zpracovává obsáhleji a poskytuje tak potřebné důkazy o validitě, které v manuálu českého vydání chybí. Např. Ryan, Rosenberg a Mittenberg (1984) podávají informace o faktorové validitě. Neurologickým pacientům $(\mathrm{N}=108)$ dali k vyplnění PTU, 3 WAIS verbální a 3 výkonové subtesty, WMS subtesty mentální kontroly, počítání (Digit Span), párového asociačního učení, logické paměti a vizuální reprodukce a všechny odpovědi podrobili faktorové analýze. Ta odhalila přítomnost čtyř faktorů vysvětlujících dohromady 75,4 \% rozptylu. PTU, párové asociace a logická pamět' zformovaly první faktor a významně se tím odlišily od testů měřících verbální a neverbální inteligenci a pozornost. Konvergentní a divergentní validitu zkoumali de Sousa Magalhães, Fernandes Malloy-Diniz a Cavalheiro Hamdan (2012) pomocí série korelací mezi PTU a různými dalšími testy na 34 zdravých participantech. Konvergentní validita $(r=0,37-0,44)$ byla nalezena mezi testy PTU a Benton Visual Retention Test (BVRT), zatímco na divergentní validitu ukazuje nesignifikantní korelace mezi PTU a Trail Making Test (TMT). Další důkazy o konvergentní validitě přináší Jafari, Steffen Moritz, Zandi, Aliakbari Kamrani a Malyeri (2010) porovnáváním perské verze PTU s WMS ( $\mathrm{r}=0,35)$ na vzorku 250 zdravých seniorů (ve věku 60 až 80 let) a 100 seniorů s Alzheimerovou demencí.

\section{Reliabilita}

Co se týče reliability, obsahuje manuál údaje o jejích důkazech pouze ze zahraničních zdrojů. Test-retest reliabilita (po jednom roce) byla 0,55 (Spreen, \& Strauss, 1991) a splithalf reliabilita kolísala mezi 0,77 a 0,86 (Kramer, 1988, as cited in Lezak, 1995). U těchto studií nejsou žádné informace o jejich probandech.

Po bližším zkoumání těchto dvou zdrojů však vyšlo najevo, že studie zkoumající split-half reliabilitu je poměrně problematická. Zaprvé je citovaná špatně, jelikož Kramer (1988) zkoumal rozdíly mezi pohlavími ve verbálním učení, ne reliabilitu. Zadruhé důkaz o reliabilitě pochází ze třech studií sledujících split-half reliabilitu (a citovaných v manuálu) Kalifornského verbálního testu učení (CVLT; Delis, Kramer, Kaplan, \& Ober, 1987), který byl vyvinutý na základě PTU, ale v některých kategoriích se od sebe liší. CVLT se skládá z 16 slov, která jsou rozdělená do 4 sémantických kategorií a prezentovaná jako nákupní seznam, protože autoři zamýšleli měřit spíše strategie a chyby v procesu zapamatování, ne jen celkové skóre, jak je PTU někdy vnímáno. Postup administrace je velmi podobný u obou testů, u CVLT je navíc instrukce pokusit se vybavit si slova podle jednotlivých sémantických skupin, což může probandům pomoci vybavit si více slov. Z porovnání CVLT a PTU na vzorku 36 zdravých probandů vyplývá, že tyto dva testy nejsou srovnatelné; liší se $\mathrm{v}$ celkovém skóre (vyšší u CVLT), křivce učení a nebyl mezi nimi nalezen efekt 
interakce, což ukazuje, že tyto testy měří různé aspekty paměti (Edwards, 1988). Crossen a Wiens (1994) zkoumali na 60 zdravých probandech efekt učení mezi PTU a CVLT. Jedné polovině byl ráno administrován PTU a odpoledne CVLT a druhé polovině ve stejný čas testy v obráceném pořadí. Výsledky ukázaly, že celkové skóre je lehce vyšší u CVLT, nicméně efekt učení se nijak neprojevil. Obě poloviny probandů měly podobně vyšší druhé skóre bez ohledu na to, kterým testem začaly.

Je očividné, že CVLT ukazuje něco trochu jiného než PTU a nelze zobecňovat zjištění, např. hodnotu split-half reliability, jednoho testu na druhý.

Z dalších zahraničních prací bych zmínila reliabilitu paralelních forem testu měřenou na 85 klinických pacientech (prům. věk=45,86 let), která se pohybuje mezi 0,60 a 0,77 (Ryan, Geisser, Randall, \& Georgemiller, 1986). Rozdíl mezi formami byl menší než 1 slovo v každém pokusu vybavení PTU. Srovnatelné výsledky ukázala i studie z roku 2004 (Lemay, Bédard, Rouleau, \& Tremblay).

Měření test-retest reliability po 3 měsících na vzorku 225 dětí (6-12 let) ukázalo hodnoty 0,70 či 0,59 po započtení vlivu věku dítěte (Van den Burg, \& Kingma, 1999) a vnitřní konzistence (Cronbachovo $\alpha$ ) jednotlivých vybavení se na stejném vzorku dětí pohybovala od 0,86 po 0,91 . V brazilské adaptaci PTU dosáhlo Cronbachovo alfa v jednotlivých pokusech vybavení hodnoty 0,85 na vzorku 223 seniorů (60 - 89 let) z běžné populace bez závažných onemocnění (Malloy-Diniz, Lasmar, Gazinelli, Fuentes, \& Salgado, 2007).

\section{Shrnutí}

Pamět'ový test učení představuje jednu z nejpoužívanějších metod určenou k měření různých aspektů paměti využitelnou $\mathrm{v}$ řadě oblastí aplikované psychologie. Tato skutečnost spolu s jednoduchostí a rychlostí administrace PTU patří mezi klady metody.

České vydání nicméně trpí některými nedostatky. Předně jsou české normy v manuálu dostupné pouze pro děti ve věku 9-14 let a pro zbylou populaci jsou normy orientační, převzaté ze zahraničí. Tyto normy se liší v mnoha parametrech (věk, pohlaví, množství zahrnutých aspektů testu apod.) a je tedy poměrně obtížné posoudit jejich kvalitu a vybrat normu pro interpretaci výsledků konkrétního probanda. Autor pro tento výběr nezmiňuje žádný postup. Fakt, že již 4 roky existují normy pro českou populaci ve věku 20-85 let zatím v manuálu není reflektován, jelikož od vydání v roce 1999 nedošlo k jeho oficiálnímu přepracování.

Další nevýhodou je neuspokojivý popis důkazů o validitě a reliabilitě, které sice lze najít v zahraniční literatuře, nicméně tyto zdroje nemusí být pro běžného uživatele testu dobře dostupné.

I přes některé nedostatky bych test určitě doporučila k použití. Dủkazy o validitě a reliabilitě jsou velmi podstatné, ale s vynaložením určitého úsilí jsou dohledatelné a 
mohou tedy doplnit chybějící údaje v oficiálním českém manuálu. Ačkoliv autor nezmiňuje postup výběru norem pro dospělou populaci, samotnou interpretaci výsledků popisuje kvalitně a nové české normy k dispozici jsou, takže testování české populace dle norem nic zásadního nebrání. Bylo by vhodné vypracovat nový manuál zahrnující již výsledky práce Bezdíčka a jeho kolegů, do té doby se díky množství kvalitních zahraničních studií dá s testem pracovat za použití externích norem. Uživatel si dokonce ani nemusí kupovat poměrně drahý manuál, nebot' je na trhu volně prodejná kniha (Preiss, Bartoš, \& Čermáková, 2013) s celým manuálem a záznamovým archem PTU (dostupná již od 85 Kč) a s dalšími testy jako bonus k tomu. Pro použití v praxi je však každopádně nezbytné, aby si český psycholog samostatně vyhledal adekvátní normy vždy pro dané použití.

\section{Zdroje}

Bezdicek, O., Stepankova, H., Moták, L., Axelrod, B. N., Woodard, J. L., Preiss, M., ... \& Poreh, A. (2014). Czech version of Rey Auditory Verbal Learning test: normative data. Aging, Neuropsychology, and Cognition, 21(6), 693-721. doi:10.1080/13825585.2013.865699

Crossen, J. R., \& Wiens, A. N. (1994). Comparison of the Auditory-Verbal Learning Test (AVLT) and California Verbal Learning Test (CVLT) in a sample of normal subjects. Journal of Clinical and Experimental Neuropsychology, 16, 190-194. doi:10.1080/01688639408402630

de Sousa Magalhães, S., Fernandes Malloy-Diniz, L., \& Cavalheiro Hamdan, A. (2012). Validity Convergent and Reliability Test-retest of the Rey Auditory Verbal Learning Test. Clinical Neuropsychiatry, 9(3), 129-137. Retrieved from: http://www.clinicalneuropsychiatry.org/pdf/03\%20magalhaes.pdf

Delis, D. C., Kramer, J. H., Kaplan, E., \& Thompkins, B. A. O. (1987). CVLT: California verbal learning test-adult version: manual. San Antonio: Psychological Corporation.

Edwards, H. F. (1988). A comparison of the Rey Auditory-Verbal Learning Test with the California Verbal Learning Test. Amedd Clinical Psychology Short Course, 90, 90-99. Retrieved from: http://www.dtic.mil/dtic/tr/fulltext/u2/a227854.pdf\#page=100

Jafari, Z., Steffen Moritz, P., Zandi, T., Aliakbari Kamrani, A., \& Malyeri, S. (2010). Psychometric properties of Persian version of the Rey Auditory-Verbal Learning Test (RAVLT) among the elderly. Iranian Journal of Psychiatry and Clinical Psychology, 16(1), 56-64.

Lemay, S., Bédard, M. A., Rouleau, I., \& Tremblay, P. L. (2004). Practice effect and test-retest reliability of attentional and executive tests in middle-aged to elderly subjects. The Clinical Neuropsychologist, 18, 284-302. doi:10.1080/13854040490501718

Lezak, M. (1995). Neuropsychological Assesment. New York: Oxford University Press.

Malloy-Diniz, L. F., Lasmar, V. A. P., Gazinelli, L. D. S. R., Fuentes, D., \& Salgado, J. V. (2007).

The Rey auditory-verbal learning test: applicability for the Brazilian elderly population. Revista Brasileira de Psiquiatria, 29, 324-329. doi:10.1590/S151644462006005000053

Mitrushina, M., Boone, K.B., Razani, J., \& D`Elia, L.F. (2005). Handbook of Normative Data for Neuropsychological Assessment. New York: Oxford University Press.

Preiss, M. (1994). Pamět’ový test učení pro klinickou praxi. Československá psychologie, 38, 257265.

Preiss, M. (1998). Pamětový test učení: metodický manuál IPPP ČR. Brno: Psychodiagnostika. Preiss, M. (1999). Pamět'ový test učení: manuál pro dospělé a děti. Brno: Psychodiagnostika. 
Preiss, M., Bartoš, A., \& Čermáková, R. (2013). Neuropsychologická baterie Psychiatrického centra Praha, 3. vydání. Praha: Psychiatrické centrum.

Preiss, M., Motejlková, J., Janů, I., \& Kolárová, E. (2001). Pamětový test učení: současné normy pro děti ve věku 9-14 let. Retrieved from: http://docplayer.cz/13455808-Pametovy-test-ucenisoucasne-normy-pro-deti-ve-veku-9-14-let.html

Ryan, J. J., Geisser, M. E., Randall, D. M., \& Georgemiller, R. J. (1986). Alternate form reliability and equivalency of the Rey Auditory Verbal Learning Test. Journal of Clinical and Experimental Neuropsychology, 8(5), 611-616. doi:10.1080/01688638608405179

Ryan, J., Rosenberg, J.S., \& Mittenberg, W. (1984). Factor analysis of the Rey Auditory-Verbal Learning Test. International Journal of Clinical Neuropsychology, 6(4), 239-241.

Spreen, O., \& Strauss, E. (1991). A compedium of neuropsychological tests. New York: Oxford University Press.

van den Burg, W., \& Kingma, A. (1999). Performance of 225 Dutch school children on Rey's Auditory Verbal Learning Test (AVLT): parallel test-retest reliabilities with an interval of 3 months and normative data. Archives of Clinical Neuropsychology, 14(6), 545-559. doi:10.1016/S0887-6177(98)00042-0 


\section{MODEL RECENZE PODLE EFPA PRO POPIS A HODNOCENÍ PSYCHOLOGICKÝCH TESTŮ FORMULÁR̆ RECENZE TESTU A POZNÁMKY PRO RECENZENTY ${ }^{1}$}

Toto je lokální úprava dokumentu pro účely publikace v časopise Testfórum.

Originální český překlad je $\mathrm{k}$ dispozici na stránkách EFPA

(www.efpa.eu/download/505cd9db4144ecb16174087909c9cd6d).

Původní verzi sestavil a uspořádal Dave Bartram

Doplnili a revidovali Patricia Lindley, Dave Bartram a Natalie Kennedy v dubnu $2004^{2}$

Současná verze 3.42: květen 2005

Český překlad: Tomáš Urbánek

Od uživatelů tohoto dokumentu a jeho obsahu žádá EFPA, aby uznali tento zdroj prostřednictvím následujícího textu:

"Kritéria pro recenzi testu podle EFPA do značné míry vychází z formy a obsahu kritérií pro recenze testů Britské psychologické společnosti (BPS) a kritérií vytvořených Komisí pro testové záležitosti (COTAN) Holandské asociace psychologů (NIP). Dave Bartram a Patricia Lindley původně vyvinuli kritéria BPS a recenzní procedury pro UK Employment Service a později rozšírili jejich používání pro celou BPS. Arne Evers připravil k vydání nizozemský system posuzování kvality testů.

EFPA je vděčná BPS a NIP za svolení použít jejich kritéria jako základ pro vytvoření evropského modelu. EFPA je také vděčná Davu Bartramovi, Arnu Eversovi a Patricii Lindley za jejich přispění $k$ vývoji tohoto modelu. Veškerá intelektuální vlastnická práva původních kritérií podle BPS a NIP jsou nadále uznávána a náleží těmto orgánưm."

\footnotetext{
${ }^{1}$ Tento dokument byl vytvořen z několika zdrojů, včetně Hodnotícího formuláře pro recenzi testu používaného v BPS (NPAL a Řídící komise pro testové standardy při BPS - Steering Committee on Test Standards), Španělského dotazníku pro hodnocení psychometrických testů (Španělská psychologická asociace) a Systému pro posuzování kvality testu (Komise pro testování Holandské asociace psychologů). Některé části byly adaptovány se svolením z dokumentu: BPS Books Reviews of Level B Assessment Instruments for use in Occupational Assessment, Notes for Reviewers: Version 3.1. December 1998: Copyright (C) NPAL, 1989, 1993, 1998.

${ }^{2}$ Současná verze je spojením dvou oddělených dokumentů (Formuláře recenze a Poznámek pro recenzenty). Obsah byl navíc uspořádán a doplněn na základě jeho používání recenzenty online testů v BPS.
} 


\section{Č́st 1:}

Popis nástroje: Obecné informace a klasifikace

\begin{tabular}{|c|c|c|}
\hline & Recenzent 1: & Bc. Jolana Stehlíková \\
\hline & Recenzent 2: & \\
\hline & Konzultující editor: & Mgr. Hynek Cígler, Ph.D. \\
\hline & Vedoucí editor: & Mgr. Hynek Cígler, Ph.D. \\
\hline & $\begin{array}{l}\text { Vedoucí editor aktualizace: } \\
\text { (pouze v př́ípadě aktualizací) }\end{array}$ & \\
\hline & $\begin{array}{l}\text { Editor aktualizace: } \\
\text { (pouze v př́padě aktualizací) }\end{array}$ & \\
\hline & Datum vzniku této recenze: & 1. 3.2018 \\
\hline 1.1 & Název nástroje (lokální verze): & Pamět'ový test učení \\
\hline & Zkrácená verze názvu testu: & PTU \\
\hline 1.2 & $\begin{array}{l}\text { Původní název testu (pokud je lokální } \\
\text { verze adaptací): }\end{array}$ & The Rey Auditory-Verbal Learning Test \\
\hline 1.4 & Autoři původního testu: & André Rey \\
\hline 1.3 & Autoři lokální adaptace: & Marek Preiss \\
\hline 1.7 & Lokální distributor/vydavatel testu: & $\begin{array}{l}\text { Psychodiagnostika, a.s., Psychiatrické } \\
\text { centrum Praha }\end{array}$ \\
\hline 1.8 & $\begin{array}{l}\text { Vydavatel původní verze testu (pokud je } \\
\text { jiný než současný distributor/vydavatel): }\end{array}$ & Není známo \\
\hline 1.9 .1 & Datum vydání současné revize/vydání: & 1998, 1999, 2013 \\
\hline 1.9 .2 & $\begin{array}{l}\text { Datum vydání adaptace pro lokální } \\
\text { užívání: }\end{array}$ & 1998 \\
\hline 1.9 .3 & Datum vydání původního testu: & 1985 \\
\hline
\end{tabular}




\section{Obecný popis nástroje}

Pamět'ový test učení (PTU) představuje metodu určenou k měření paměti, zejména bezprostřední a krátkodobé verbální paměti. Ta se v testu projevuje množstvím zapamatovaných slov ze dvou sad (A a B). PTU obsahuje 2 sady slov po 15 slovech; první sada (A) je čtena $5 x$ a po každém přečtení má respondent za úkol vyjmenovat co nejvíce zapamatovaných slov ve volném pořadí. Poté následuje druhá sada (B) a její vybavení a následně je proband požádán opětovně si vybavit co nejvíce slov ze sady A. Po 30 minutách následuje oddálené vybavení sady A, poté rekognice v podobě seznamu slov ze sad A a B a jejich fonetických a sémantických asociací, u nichž má proband vždy říci, zda se slovo nacházelo v sadě $A$.

Metoda měří hned několik dílčích aspektů paměti. Předně jde o bezprostřední a krátkodobou verbální pamět', vybavování slov ihned po jejich přečtení administrátorem, vybavování po distrakci, oddálené vybavení, rekognici slov a v neposlední řadě o proces učení. Test také sleduje míru opakování slov (kolikrát si respondent vybaví jednotlivá slova) a výskyt konfabulací (kolik vybavených slov nepatří mezi danou sadu A nebo B)

Test je dle manuálu možné využít $\mathrm{v}$ mnoha kontextech. Je vhodný pro rutinní psychodiagnostiku $\mathrm{v}$ poradenství, klinické psychologii a pro posudkovou činnost. Diagnostikuje organické oslabení CNS, poruchy učení u dětí a demenci u dospělých (zvláště její počáteční formy). Jeho aplikace je doporučovaná i pro sledování následkủ úrazu hlavy a při diferenciální diagnostice poruch paměti (organické vs. funkční poruchy paměti).

Původní verze testu, Rey-Auditory-Verbal Learning Test (RAVLT) od Švýcara A. Reye pochází z roku 1958. Samotné české vydání (Preiss, 1994) vychází částečně ze švýcarského originálu a jeho americké adaptace a částečně je doplněno novými slovy.

Čas potřebný $\mathrm{k}$ administraci testu je v manuálu odhadnutý na 10 minut, nicméně test nemá žádný omezený čas, jelikož se čeká, dokud respondent neřekne, že už si nic nevybavuje. PTU je možno administrovat bud' individuálně, nebo skupinově s tím, že ve skupině probandi zapisují sami vybavená slova a administrátor následně vyplní jejich záznamové archy.

Pořizovací náklady na test činí 2439 Kč bez DPH a v ceně je zahrnuta příručka pro práci s testem a 200 záznamových archů pro děti a 200 pro dospělé.

Získané hodnoty lze interpretovat na celkem 8 škálách. Vybavení 1-5 je 5 součtů slov, které si proband vybaví ihned po přečtení sady slov. Počet opakování slov vyjadřuje součet všech slov, která si proband vybaví $2 \mathrm{x}$ a vícekrát $\mathrm{v}$ jednom pokusu vybavování. Počet konfabulací představuje počet vybavených slov, která nepatř́ do dané sady slov. Opakování i konfabulace se zapisují jak pro jednotlivé pokusy, tak v celkovém počtu za prvních pět pokusů. Celkový výkon je součtem všech správně vybavených položek z prvních pěti pokusů. Výkon v sadě B ukazuje počet vybavených slov z distrakční sady B a zároveň stálost výkonu probanda (v porovnání s prvním pokusem sady A). Vybavení sady A po distrakci sadou B značí počet správně vybavených položek ze sady A po sadě B. Oddálené vybavení sady A ukazuje počet vybavených slov ze sady A po 30 minutách. Rekognice značí počet správně označených slov patř́cích do sady A při expozici distraktorů v podobě sady $\mathrm{B}$ a fonetických nebo sémantických asociací sad A a B.

Interpretace výsledků probíhá na základě hrubých skórů získaných ve výše popsaných škálách, neprovádí se transformace na standardní skóry, nicméně ve většině orientačních norem jsou $\mathrm{k}$ dispozici průměry a směrodatné odchylky, takže transformace skórů možná je, pokud to povaha vyšetření vyžaduje. 


\section{Část 2: \\ Klasifikace}

\begin{tabular}{|c|c|c|}
\hline 1.10 .1 & Obsahová doména & $\begin{array}{l}\text { Školní schopnosti } \\
\square \text { Všeobecné schopnosti } \\
\square \text { Verbální schopnosti } \\
\square \text { Numerické schopnosti } \\
\square \text { Prostorové schopnosti } \\
\square \text { Neverbální schopnosti } \\
\square \text { Rychlost vnímání } \\
\text { 囚Pamět' } \\
\square \text { Manuální zručnost } \\
\square \text { Osobnost - Rys } \\
\square \text { Osobnost - Typ } \\
\square \text { Osobnost - Stav } \\
\square \text { Kognitivní styly } \\
\square \text { Motivace } \\
\square \text { Hodnoty } \\
\square \text { Zájmy } \\
\square \text { Přesvědčení } \\
\square \text { Poruchy a patologie } \\
\square \text { Skupinové procesy } \\
\square \text { Rodina } \\
\square \text { Organizace, její fungování, agregovaná } \\
\text { měření, klima atd. } \\
\square \text { Školní nebo výchovné funkce } \\
\text { 囚 Jiné: proces učení }\end{array}$ \\
\hline 1.10 .2 & $\begin{array}{l}\text { Zamýšlená(é) nebo hlavní oblast(i) } \\
\text { použití. }\end{array}$ & $\begin{array}{l}\text { 囚 Klinická psychologie } \\
\text { 囚 Neuropsychologie } \\
\square \text { Forenzní psychologie } \\
\text { 囚 Psychologie výchovy a vzdělávání } \\
\square \text { Psychologie práce a personalistika } \\
\square \text { Poradenství, doporučení, vedení a volba } \\
\quad \text { povolání } \\
\square \text { Psychologie zdraví, životní styl a životní } \\
\quad \text { spokojenost } \\
\square \text { Sporty a volný čas } \\
\square \text { Jiné: }\end{array}$ \\
\hline 1.10 .3 & $\begin{array}{l}\text { Zamýšlený způsob použití } \\
\text { (podmínky, za jakých byl nástroj } \\
\text { standardizován a validizován) }\end{array}$ & $\begin{array}{l}\text { Nesupervidovaná administrace bez } \\
\text { kontroly nad identitou respondenta a bez } \\
\text { úplné kontroly nad podmínkami } \\
\text { administrace (např. volně pŕístupný test } \\
\text { na internetu, test dostupný ke koupi v } \\
\text { knihkupectví). } \\
\square \text { Kontrolovaný nesupervidovanou } \\
\text { administrcí. Kontrola nad podmínkami } \\
\text { (čas atd.) a určitá kontrola nad identitou } \\
\text { uživatele testu (např. testy } \\
\text { administrované přes internet, ale pouze } \\
\text { známým osobám - př́stup omezený }\end{array}$ \\
\hline
\end{tabular}




\begin{tabular}{|c|c|c|}
\hline & & $\begin{array}{l}\text { heslem). } \\
\text { 囚 Supervidovaná a kontrolovaná } \\
\text { administrace. Administrace testu pod } \\
\text { kontrolou kvalifikovaného adminitrátora } \\
\text { nebo dohlížitele. } \\
\square \text { Řízená administrace. Administrace testu } \\
\text { prováděná pouze přes určená testovací } \\
\text { centra (např. programy hodnocení licencí }\end{array}$ \\
\hline & & a certifikace). \\
\hline 1.10 .4 & $\begin{array}{l}\text { Popis populací, pro které je test } \\
\text { určen: }\end{array}$ & $\begin{array}{l}\text { Metoda je určena pro muže a ženy od } 9 \text { do } 89 \\
\text { let. Mezi } 9 \text { a } 14 \text { roky života je v rámci českých } \\
\text { norem populace, pro kterou je test určen, dále } \\
\text { členěna po jednotlivých letech a podle pohlaví. } \\
\text { Dále jsou orientační normy členěny po různých } \\
\text { věkových skupinách a pro rozdělená i smíšená } \\
\text { pohlaví. }\end{array}$ \\
\hline 1.10 .5 & $\begin{array}{l}\text { Počet škál a krátký popis } \\
\text { proménné nebo proměnných } \\
\text { měřených nástrojem }\end{array}$ & $\begin{array}{l}\text { Získané hodnoty lze interpretovat na celkem } 8 \\
\text { škálách. } \\
\text { Vybavení 1-5 je } 5 \text { součtů slov, které si proband } \\
\text { vybaví ihned po přečtení sady slov. } \\
\text { Počet opakování slov vyjadřuje součet všech } \\
\text { slov, která si proband vybaví } 2 x \text { a vícekrát v } \\
\text { jednom pokusu vybavování. } \\
\text { Počet konfabulací představuje počet } \\
\text { vybavených slov, která nepatř́ do dané sady slov. } \\
\text { Opakování i konfabulace se zapisují jak pro } \\
\text { jednotlivé pokusy, tak v celkovém počtu za } \\
\text { prvních pět pokusů. } \\
\text { Celkový výkon je součtem všech správně } \\
\text { vybavených položek z prvních pěti pokusư. } \\
\text { Výkon v sadě B ukazuje počet vybavených slov z } \\
\text { distrakční sady B a zároveň stálost výkonu } \\
\text { probanda (v porovnání s prvním pokusem sady } \\
\text { A). } \\
\text { Vybavení sady A po distrakci sadou B značí } \\
\text { počet správně vybavených položek ze sady A po } \\
\text { sadě B. } \\
\text { Oddálené vybavení sady A ukazuje počet } \\
\text { vybavených slov ze sady A po } 30 \text { minutách. } \\
\text { Rekognice značí počet správně označených slov } \\
\text { patřících do sady A při expozici distraktorů v } \\
\text { podobé sady B a fonetických nebo sémantických } \\
\text { asociací sad A a B. }\end{array}$ \\
\hline 1.11 & Formát položek & $\begin{array}{l}\square \text { Otevřený } \\
\square \text { Mnohonásobná volba, alternativy na stejné } \\
\text { škále } \\
\square \text { Bipolární adjektiva } \\
\square \text { Likertovy ratingy (škály) } \\
\square \text { Nucená volba, alternativy na smíšených }\end{array}$ \\
\hline
\end{tabular}




\begin{tabular}{|c|c|c|c|}
\hline & & \multicolumn{2}{|c|}{$\begin{array}{l}\text { škálách (ipsativní) - vysvětlení viz } \\
\text { Poznámky } \\
\square \text { Mnohonásobná volba, alternativy na } \\
\text { smíšených škálách (ipsativní) - vysvětlení } \\
\text { viz Poznámky } \\
\square \text { Sady párů adjektiv (sémantický } \\
\text { diferenciál), smíšené škály (ipsativní) } \\
\text { 叉 Jiné: } \quad \text { Čtený seznam } \\
\end{array}$} \\
\hline 1.12 & Počet položek testu: & \multicolumn{2}{|c|}{30 slov ve dvou sadách, 50 slov pro rekognici } \\
\hline 1.13 & Způsob(y) administrace: & \multicolumn{2}{|c|}{$\begin{array}{l}\text { 区 Interaktivní individuální administrace } \\
\text { 囚 Supervidovaná skupinová administrace } \\
\square \text { Počítačová lokálně nainstalovaná aplikace } \\
\text { - pod supervizí/dohledem } \\
\square \text { Počítačová aplikace na webu - pod } \\
\text { supervizí/dohledem } \\
\square \text { Počítačová lokálně nainstalovaná aplikace } \\
\text { - bez supervise/testování sebe } \\
\square \text { Počítačová aplikace na webu - bez } \\
\text { supervize/testování sebe } \\
\square \text { Jiné: }\end{array}$} \\
\hline 1.14 & Způsob odpovídání: & \multicolumn{2}{|c|}{$\begin{array}{l}\square \text { Ustní rozhovor } \\
\text { 囚 Papír a tužka } \\
\square \text { Manuální operace } \\
\square \text { Na počítači } \\
\text { 囚 Jiné: vybavování nahlas, zapisuje } \\
\text { administrátor }\end{array}$} \\
\hline 1.15 & $\begin{array}{l}\text { Čas potřebný pro administraci } \\
\text { nástroje: } \\
\text { Čas na př́ípravu (čas, který zabere } \\
\text { administrátorovi připravit a rozložit materiály } \\
\text { pro diagnostické sezení). } \\
\text { Čas na administraci na sezení: zahrnuje } \\
\text { čas potřebný pro dokončení všech } \\
\text { položek a odhad času potř́bného pro } \\
\text { podání instrukcí, projití zácvičných } \\
\text { položek a nějaké doplňujíć komentáře na } \\
\text { konci sezení. } \\
\text { Skórování: čas nutný pro získání hrubých } \\
\text { skórù. } \\
\text { Analýza: čas strávený prováděním dalších } \\
\text { prací s hrubými skóry, aby se z nich } \\
\text { odvodily další míry a zformulovala } \\
\text { rozumně úplná interpretace (za } \\
\text { předpokladu, že znáte nástroj). } \\
\text { Zpětná vazba: čas potřebný k př́pravě a } \\
\text { poskytnutí zpětné vazny vyšetřované } \\
\text { osobě. } \\
\text { Připouští se, že čas posledních dvou } \\
\text { komponent se mǔže značně lišit - v závislosti } \\
\text { na kontextu, ve kterém se nástroj používá. Ale }\end{array}$ & $\begin{array}{l}\text { Příprava: } \\
\text { Administrace: } \\
\text { Skórování: } \\
\text { Analýza: } \\
\text { Zpětná vazba: }\end{array}$ & $\begin{array}{l}\text { Cca } 1 \text { minuta } \\
\text { Cca } 10 \text { minut } \\
\text { neuvedeno } \\
\text { neuvedeno } \\
\text { neuvedeno }\end{array}$ \\
\hline
\end{tabular}




\begin{tabular}{|l|l|l|l|}
\hline & $\begin{array}{l}\text { aspoň nějaké údaje a komentáře budou } \\
\text { užitečné. }\end{array}$ & & \\
\hline 1.16 & $\begin{array}{l}\text { Jsou k dispozici rưzné formy } \\
\text { nástroje? }\end{array}$ & $\begin{array}{l}\text { PTU je k dispozici v tištěné formě, } \\
\text { počítačová forma neexistuje. Test má } \\
\text { nicméně k dispozici paralelní sady } \\
\text { slov pro možnost opakovaného } \\
\text { testování. }\end{array}$ \\
\hline & & \\
\hline
\end{tabular}


Č́ást 3:

Měření a skórování

\begin{tabular}{|c|c|c|}
\hline 1.17 & Procedura skórování testu: & $\begin{array}{l}\square \text { Počítačové skórování s přímým vstupem } \\
\text { odpovědí testovanou osobou } \\
\square \text { Počítačové skórování s ručním vstupem } \\
\text { odpovědí z papírového záznamového archu } \\
\square \text { Počítačové skórování odpovědí z papírového } \\
\text { záznamového archu pomocí pomocí jejich } \\
\text { načtení pomocí skeneru } \\
\text { 区 Jednoduchý ruční skórovací klíč - nutné } \\
\text { pouze kancelářské dovednosti } \\
\square \text { Komplexní ruční skórování - vyžadující } \\
\text { trénink ve skórování nástroje } \\
\square \text { Služby zpracování dat - naprr. skórování } \\
\text { společností prodávající nástroj } \\
\square \text { Jiné: }\end{array}$ \\
\hline 1.18 & Skóry: & $\begin{array}{l}\text { Způsob výpočtu hodnot pro jednotlivé škály je } \\
\text { nastíněn v části } 1.10 .5 \text {. Interpretace výsledků } \\
\text { probíhá na základě hrubých skórů získaných ve } \\
\text { výše popsaných škálách. }\end{array}$ \\
\hline 1.19 & $\begin{array}{l}\text { Transformace skóru na standardní } \\
\text { skóry: }\end{array}$ & $\begin{array}{l}\text { Normalizovaná - skóry se získají použitím } \\
\text { normalizační tabulky } \\
\square \text { Nenormalizovaná - skóry se získají lineární } \\
\text { Transformací } \\
\text { 囚Jiné: } \\
\text { Neprovádí se transformace na standardní skóry, } \\
\text { nicméně ve většině orientačních norem jsou k } \\
\text { dispozici prumerry a směrodatné odchylky, takže } \\
\text { transformace skórú možná je, pokud to povaha } \\
\text { vyšetření vyžaduje. }\end{array}$ \\
\hline 1.20 & Použité škály & 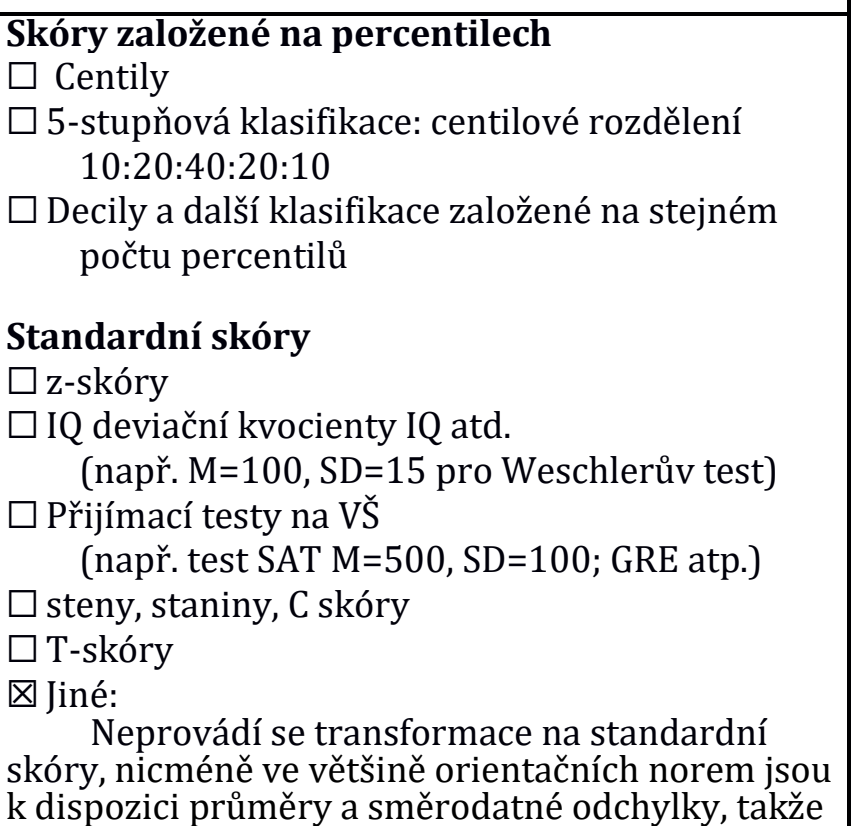 \\
\hline
\end{tabular}




\begin{tabular}{|l|l|l|}
\hline & & $\begin{array}{l}\text { transformace skórů možná je, pokud to povaha } \\
\text { vyšetření vyžaduje. }\end{array}$ \\
\hline & & \\
\hline
\end{tabular}

\begin{tabular}{l} 
Č́st $4:$ \\
Počítačově generované zprávy \\
Toto je čistě popisné. Hodnocení zpráv bude součástí části recenze nazvané Hodnocení. \\
\hline 1.21 \\
$\begin{array}{l}\text { Jsou počítačově generované zprávy } \mathbf{k} \\
\text { dispozici s nástrojem? }\end{array}$
\end{tabular}

\section{Část 5: \\ Nabídka, podmínky a náklady}

Tato část definuje, co vydavatel poskytne, komu, za jakých podmínek a za jaké ceny. Definuje podmínky kladené dodavatelem a týkající se toho, kdo smí a kdo nesmí získat materiál nástroje. Pokud jedna z možností neodpovídá podmínkám nabídky, doplňte popis relevantních podmínek.

\begin{tabular}{|c|c|c|}
\hline 1.23 & $\begin{array}{l}\text { Dokumentace poskytovaná } \\
\text { distributorem jako součást } \\
\text { testového balíku }\end{array}$ & \begin{tabular}{|l} 
区 Uživatelský manuál \\
囚 Technický (psychometrický) manuál \\
$\square$ Doplňkové technické informace a aktualizace \\
(např. lokální normy, lokální validizační studie \\
atd.) \\
$\square$ Rozšiřující informace v podobě knih a článků k \\
tématu \\
$\square$ Kombinace výše uvedených (uved'te)
\end{tabular} \\
\hline 1.24 & Metody publikace & $\begin{array}{l}\text { 区 Papír } \\
\square \text { PC - Diskety } \\
\square \text { PC - CD/ROM } \\
\square \text { Download z internetu } \\
\square \text { Živý internet (nástroj pracuje v internetovém } \\
\quad \text { prohlížeči) } \\
\square \text { Jiné: }\end{array}$ \\
\hline 1.25 .1 & $\begin{array}{l}\text { Počáteční náklady. } \\
\text { Cena kompletní sady materiálo̊ (všechny manuály } \\
\text { a dalšś material nutný k aspoň jedné zkušební } \\
\text { administraci). Kolik uchazečú lze vyšetřovat } \\
\text { pomocí materiálú získaných za počáteční náklady, } \\
\text { kde tyto náklady zahrnují materially pro } \\
\text { opakované vyšetření. }\end{array}$ & $\begin{array}{l}\text { Pořizovací náklady na test činí } 2439 \text { Kč bez DPH a v ceně } \\
\text { je zahrnuta př́ručka pro práci s testem a } 200 \\
\text { záznamových archů pro děti a } 200 \text { pro dospělé. } \\
\text { Test je také včetně manuálu a norem dostupný v knize } \\
\text { Neuropsychologická baterie Psychiatrického centra Praha } \\
\text { v ceně od } 80 \text { Kč (Preiss, Bartoš, \& Čermáková, 2013). }\end{array}$ \\
\hline 1.25 .2 & Opakující se náklady: & Nejsou známy. \\
\hline 1.26 .1 & $\begin{array}{l}\text { Ceny za zprávy generované } \\
\text { softwarem nainstalovaným } \\
\text { uživatelem: }\end{array}$ & Není k dispozici. \\
\hline 1.26 .2 & $\begin{array}{l}\text { Ceny za vyhotovení zprávy } \\
\text { zaslané } \\
\text { prostřednictvím pošty/faxu: }\end{array}$ & Není k dispozici. \\
\hline
\end{tabular}




\begin{tabular}{|c|c|c|}
\hline 1.26 .3 & $\begin{array}{l}\text { Ceny za vyhotovení zprávy } \\
\text { zaslané } \\
\text { prostřednictvím internetové } \\
\text { služby: }\end{array}$ & Není k dispozici. \\
\hline 1.27 & $\begin{array}{l}\text { Ceny za další služby a zpracování } \\
\text { dat: opravy nebo vývoj } \\
\text { automatických zpráv: }\end{array}$ & Není k dispozici. \\
\hline 1.28 & $\begin{array}{l}\text { Kvalifikační požadavky na práci } \\
\text { s testem vyžadované dodavatelem } \\
\text { testu }\end{array}$ & $\begin{array}{l}\text { 区 Žádné } \\
\square \text { Oprávnění (certifikát) pro specifický test } \\
\square \text { Oprávnění (certifikát) pro obecné výkonové } \\
\text { testy: i. e. míry maximálního výkonu ve } \\
\text { schopnostech } \\
\square \text { Potvrzení v testování obecných schopností a } \\
\text { dovedností: míry maximálního výkonu ve } \\
\text { vztahu k potenciálu k výkonu } \\
\square \text { Potvrzení v obecné diagnostice a diagnostice } \\
\text { osobnosti: míry typického chování, postojů a } \\
\text { preferencí } \\
\square \text { jiné: }\end{array}$ \\
\hline 1.29 & $\begin{array}{l}\text { Profesionální kvalifikace } \\
\text { vyžadovaná pro používání } \\
\text { nástroje }\end{array}$ & 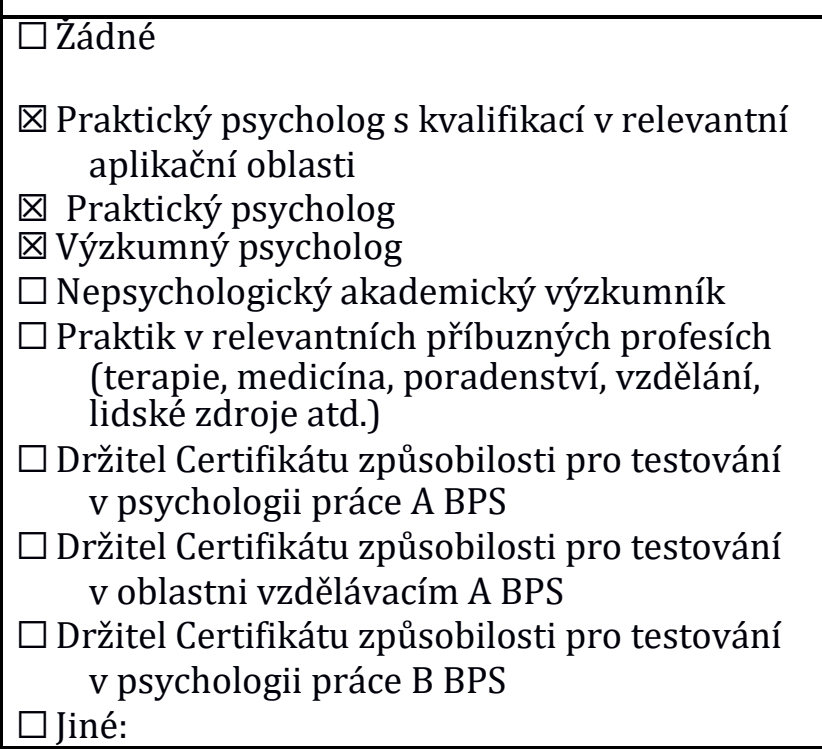 \\
\hline
\end{tabular}




\section{Část 6:}

\section{Hodnocení testových materiálů}

\section{Vysvětlení hodnocení}

V následujících částech jsou celková posouzení adekvátnosti informací týkajících se validity, reliability a norem zobrazeny automaticky tučně.

Jakýkoli nástroj s jedním nebo více posouzeními 0 nebo 2 týkajícími se atributů považovaných za kritické pro bezpečné používání nástroje, by neměl být považován za nástroj, který splňuje minimální standardy.

\begin{tabular}{|c|c|c|c|}
\hline $\begin{array}{c}\text { Vstup na posuzovacím } \\
\text { formuláŕi }\end{array}$ & $\begin{array}{l}\text { Posouzení podle } \\
\text { standardů EFPA }\end{array}$ & $\begin{array}{c}\text { Reprezentace recenze } v \\
\mathrm{UK} \\
\end{array}$ & Vysvětlení \\
\hline$[\mathrm{n} / \mathrm{a}]$ & [n/a ] & n/a & Tento atribut není u tohoto \\
\hline & & & nástroje použitelný \\
\hline $\mathbf{0}$ & {$\left[\begin{array}{ll}- & ]\end{array}\right.$} & [None ] & $\begin{array}{c}\text { Není možné posoudit jako ne } \\
\text { nebo nedostatek }\end{array}$ \\
\hline & & & poskytnutých informací \\
\hline 1 & {$[-1$} & {$[*$} & Neadekvátní \\
\hline 2 & & {$[* *$} & NYNÍ NEPOUŽÍVÁNO \\
\hline 3 & $\overline{0}$ & {$[* * *$} & Adekvátní nebo přiměřený \\
\hline & & & \\
\hline 4 & 1 & [**** & Dobrý \\
\hline 5 & 2 & {$[* * * * *]$} & Vynikající \\
\hline & & & \\
\hline & & [N.r.i.o.r] * (pouze pro & Položka nebyla v původní \\
\hline & & aktualizace) & recenzi posuzována \\
\hline
\end{tabular}

V této části má být provedeno více hodnocení různých aspektů nebo atributů dokumentace dodávané s nástrojem (nebo balíkem). Termín „dokumentace“ byl vybrán, aby pokrýval všechny ty materiály dodávané s nástrojem nebo snadno dostupné kvalifikovanému uživateli: např. manual administrátora; technické př́ručky; brožury s normami; dodatky k manuálu; aktualizace od vydavatelů/dodavatelů atd.

Položky mají být posuzovány n/a nebo 0 až 5 (poloviční rating je přijatelný)

\begin{tabular}{|c|c|c|}
\hline \multicolumn{2}{|c|}{$\begin{array}{l}\text { Kvalita vysvětlení principů, prezentace a kvalita poskytnuté informace: } \\
\text { (Tento celkový rating se získá použitím posouzení založeného na ratinzích daných pro položky 2.1-2.8) }\end{array}$} & 3,5 \\
\hline 2.1 & $\begin{array}{l}\text { Celkový rating kvality vysvětlení principů: (Tento celkový rating se získá použitím } \\
\text { posouzení založeného na hodnotách ratingů daných pro položky } 2.1 .1-2.1 .5)\end{array}$ & 1,5 \\
\hline 2.1 .1 & i) Teoretické základy konstruktů: & 3 \\
\hline 2.1 .2 & ii) Procedura vývoje testu: & 1 \\
\hline 2.1 .3 & iii) Důkladnost analýz položek a model analýzy položek: & 0 \\
\hline 2.1 .4 & iv) Vysvětlení obsahové validity: & 1 \\
\hline 2.1 .5 & v) Souhrn relevantního výzkumu: & 3 \\
\hline 2.2 & $\begin{array}{l}\text { Adekvátnost dokumentace dostupné uživateli (uživatelské a technické } \\
\text { manuály, dodatky týkající se norem atd.): (Tento celkový rating se získá použitím } \\
\text { posouzení založeného na hodnotách ratingů daných pro položky } 2.2 .1-2.2 .6) \\
\text { Pro část } 2.2 \text { jsou stanoveny následující „měřítka“ pro rating „vynikajíci“ (5). Pozornost je zde zaměřena } \\
\text { na kvalitu pokrytí poskytnutého v dokumentaci dostupné kvalifikovaným uživatelům. Všimněte si, že část } \\
2.2 \text { se týká úplnosti a jasnosti dokumentace dostupné uživateli (uživatelské a technické manually, doadtky } \\
\text { k normám atd.) v pojmech pokrytía vysvětlení. V pojmech kvality nástroje, jak ji dosvědčuje dokumentace, } \\
\text { jsou rozpracovány oblasti v této části pod čísly: } 2.1,2.3,2.9,2.10 \text { a } 2.11 \text {. }\end{array}$ & 1,5 \\
\hline 2.2 .1 & $\begin{array}{l}\text { Principy: [viz 2.1] } \\
\text { Dobře argumentovaný a jasně prezentovaný popis toho, co má podle návrhu měřit a proč byl zkonstruován } \\
\text { tak, jak je. }\end{array}$ & 3 \\
\hline 2.2 .2 & $\begin{array}{l}\text { Vývoj: } \\
\text { Úplné detaily týkající se zdrojů položek, pilotáže, analýz položek, srovnávacích studií a změn prováděných v } \\
\text { průběhu vývojových pokusů. }\end{array}$ & 0 \\
\hline
\end{tabular}




\begin{tabular}{|c|c|c|}
\hline 2.2 .3 & $\begin{array}{l}\text { Standardizace: } \\
\text { Jasné a detailní informace poskytnuté o velikostech a zdrojích standardizačního souboru a standardizační } \\
\text { proceduře. }\end{array}$ & 3 \\
\hline 2.2 .4 & $\begin{array}{l}\text { Normy: } \\
\text { Jasné a detailní informace poskytnuté o velikostech a zdrojích normalizačních skupin, podmínkách vyšetření } \\
\text { atd. }\end{array}$ & 5 \\
\hline $\begin{array}{l}2.2 .5 \\
\end{array}$ & $\begin{array}{l}\text { Reliabilita: } \\
\text { Dobré vysvětlení reliability a široký rozsah měr vnitřní konsistence a retestu spolu s vysvětlením jejich } \\
\text { relevance a zobecnitelnosti nástroje vyšstření. }\end{array}$ & 1 \\
\hline 2.2 .6 & $\begin{array}{l}\text { Validita: } \\
\text { Dobré vysvětlení validity spolu s širokou škálou studíi jasně a poctivě popsaných. }\end{array}$ & 1 \\
\hline 2.3 & $\begin{array}{l}\text { Kvalita procedurálních instrukcí poskytnutých uživateli: (Tento celkový rating se } \\
\text { získá s použitím posouzení na základě hodnot ratingů daných pro položky 2.3.1-2.3.7) }\end{array}$ & 3,5 \\
\hline 2.3 .1 & $\begin{array}{l}\text { Pro administraci testu: } \\
\text { Poskytnutá jasná a detailní vysvětlení a procedurální průvodce krok za krokem spolu s dobrými radami } \\
\text { týkajícícmi se otázek uchazečú a problémových situací. }\end{array}$ & 4 \\
\hline $\begin{array}{l}2.3 .2 \\
\end{array}$ & $\begin{array}{l}\text { Pro skórování testu, normy atd.: } \\
\text { Poskytnuté jasné a detailní informace spolu s popsanými kontrolami pro vyhnutí se možným chybám } \\
\text { skórování. }\end{array}$ & 5 \\
\hline $\begin{array}{ll}2.3 .3 \\
\end{array}$ & $\begin{array}{l}\text { Pro interpretaci a vytváření zpráv: } \\
\text { Detailní doporučení týkajííí se interpretace různých skóruos, chápání normativních měr a zacházení se vztahy } \\
\text { mezi různými škálami, s množstvím ilustrativních př́kladů a př́padových studíi. }\end{array}$ & 4 \\
\hline 2.3 .4 & $\begin{array}{l}\text { Pro poskytnutí zpětné vazby a debriefingu respondentům testu a dalším: } \\
\text { Detailní doporučení, jak prezentovat zpětnou vazbu uchazečům. }\end{array}$ & 0 \\
\hline 2.3 .5 & $\begin{array}{l}\text { Pro poskytování dobrých praktických témat týkajících se poctivosti a } \\
\text { zkreslení: } \\
\text { Uvedení detailních informací o studiích sexuálního a etnického zkreslenís relevantními varováními týkajícími } \\
\text { se použivání a zobecñování validit. }\end{array}$ & 1 \\
\hline 2.3 .6 & $\begin{array}{l}\text { Omezení používání: } \\
\text { Jasné popisy, kdo by měl a kdo by neměl být vyšetřován spolu s dobře vysvětlenými odůvodněními těchto } \\
\text { omezení (napřr. typy nezpůsobilostí, požadované úrovně gramotnosti atd.). }\end{array}$ & 5 \\
\hline 2.3 .7 & $\begin{array}{l}\text { Reference a podpůrné materiály: } \\
\text { Detailní odkazy na relevantní podpůrnou akademickou literature a křízové odkazy na další příbuzné } \\
\text { materially týkající se diagnostických nástrojü. }\end{array}$ & 4 \\
\hline $\begin{array}{l}\text { Kva } \\
\text { (Tent }\end{array}$ & $\begin{array}{l}\text { Materiálů: } \\
\text { ový rating se získá použitím posouzení založeného na hodnotách ratingů pro položky } 2.4-2.8 \text { ) }\end{array}$ & 4 \\
\hline 2.4 & $\begin{array}{l}\text { Všeobecná kvalita materiálů testu } \\
\text { (testové brožury, odpověd'ové archy, testové objekty, software atd.): }\end{array}$ & 3 \\
\hline 2.5 & Kvalita lokální adaptace testu (pokud byl test přeložen a adaptován do místního jazyka): & 4 \\
\hline 2.6 & Snadnost, s jakou může respondent testu porozumět úkolu: & 5 \\
\hline 2.7 & $\begin{array}{l}\text { Snadnost, s jakou mohou být respondentem testu tvořeny reakce nebo } \\
\text { odpovědi: }\end{array}$ & 5 \\
\hline 2.8 & Kvalita položek: & 3 \\
\hline \multicolumn{3}{|c|}{$\begin{array}{l}\text { Recenzentovy komentáře týkající se dokumentace: } \\
\text { (komentáře principů, designu, vývoje testu a jeho přijatelnosti) }\end{array}$} \\
\hline \multicolumn{3}{|c|}{$\begin{array}{l}\text { Manuál k PTU je dostupný ve třech formách. První manuál vydaný v roce 1998 společností } \\
\text { Psychodiagnostika a.s. (Preiss, 1998) a druhý vydaný v roce } 1999 \text { tamtéž (Preiss, 1999) se od sebe liší } \\
\text { pouze mírně. Největší rozdíl mezi nimi je absence orientačních norem pro dospělé v manuálu z roku } \\
\text { 1998. Test je také včetně manuálu a norem dostupný v knize Neuropsychologická baterie } \\
\text { Psychiatrického centra Praha (Preiss, Bartoš, \& Čermáková, 2013), spolu s dalšími testy jako ACE-R, } \\
\text { Trail making test apod. V této knize je méně prostoru věnováno vývoji českých norem a } \\
\text { psychometrickým charakteristikám, nicméně jsou zde některé novější zahraniční (orientační) normy } \\
\text { pro dospělé. }\end{array}$} \\
\hline
\end{tabular}


Část 7:

Hodnocení norem, reliability a validity

\section{Informace o normách nebo referenční skupině}

\begin{tabular}{|c|c|c|}
\hline 2.9 & Celková adekvátnost: & 5 \\
\hline 2.9 .1 & $\begin{array}{cl}\begin{array}{l}\text { Vhodnost pro lokální použití, at' už pro lokální nebo mezinárodní normy: } \\
\text { [n/a] }\end{array} & \text { Nepoužitelné } \\
0 & \text { Žádná informace nepodána. } \\
1 & \text { Není lokálně relevantní (např. nevhodné zahraniční výběry). } \\
3 & \begin{array}{l}\text { Lokální výběr z obecné populace nebo nelokální normy, které lze } \\
\text { použít s varováním. }\end{array} \\
4 & \begin{array}{l}\text { Výběry lokální země nebo relevantní mezinárodní výběry s dobrou } \\
\text { relevancí pro zamýšlenou aplikaci. }\end{array} \\
5 & \begin{array}{l}\text { Výběry lokální země nebo relevantní mezinárodní výběry vybrané z } \\
\text { dobře definovaných výběrủ z relevantních aplikačních oblastí. }\end{array}\end{array}$ & 5 \\
\hline 2.9 .2 & 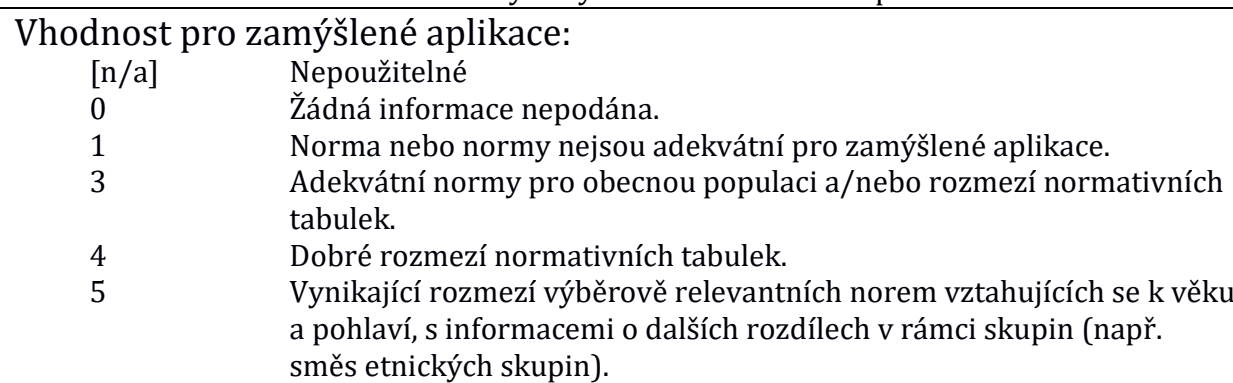 & 5 \\
\hline 2.9 .3 & 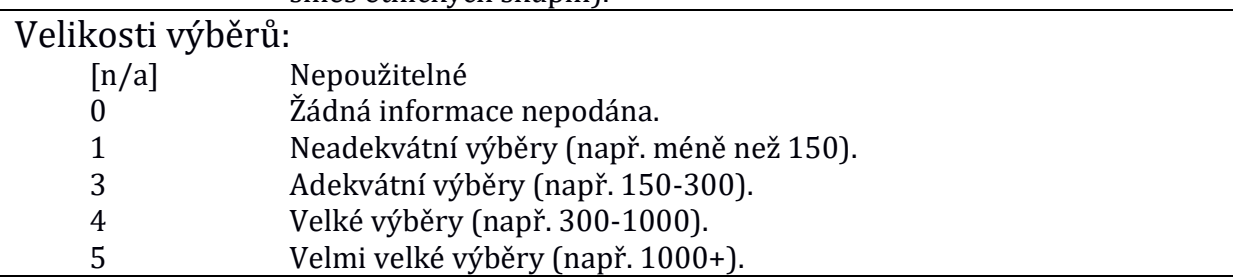 & 4 \\
\hline 2.9 .4 & $\begin{array}{cl}\text { Procedury použité při výběru souboru: } \\
\square & \text { Žádná informace neposkytnuta } \\
\square & \text { Reprezentativní populaci [sumarizujte kritéria] } \\
\square & \text { Nahodilá } \\
\square & \text { Náhodná }\end{array}$ & \\
\hline 2.9 .5 & 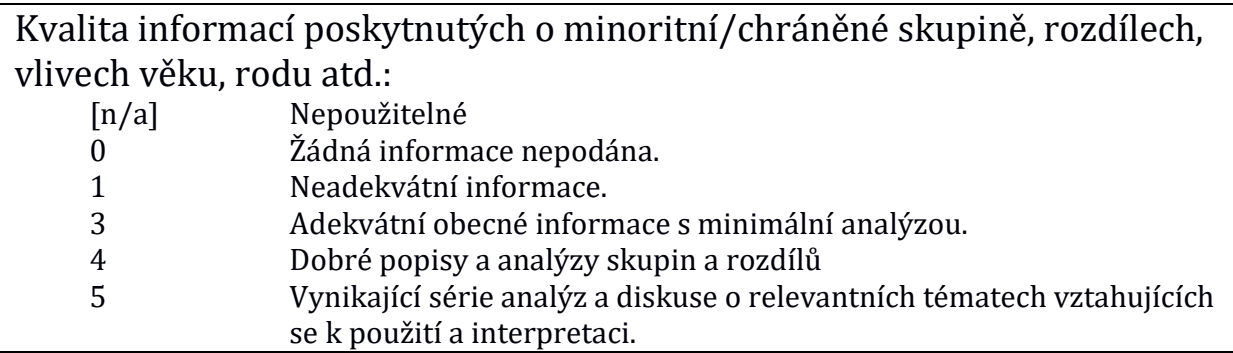 & 5 \\
\hline
\end{tabular}

2.9.6 Komentáře recenzentů k normám: Stručná zpráva o normách a jejich historii, včetně informací o doporučeních učiněných vydavatelem/autorem pro aktualizaci norem obvyklým způsobem.

Normy, ze kterých vychází české vydání PTU byly vytvořeny na standardizačním vzorku 182 dětí (102 chlapců a 80 dívek) z různých pražských ZŠ ve věku 9-14 let. V každém věkovém pásmu bylo vyšetřeno 
30 dětí kromě jedenáctiletých $(\mathrm{N}=32)$. Normy jsou rozděleny zvlášt' pro dívky a chlapce po jednotlivých rocích. Autor nijak nevysvětluje důvody pro rozdělení norem po letech a pohlaví, nicméně ve shrnutí výsledků uvádí, že dívky mají vyšší skóre opakování a jsou lepší než chlapci v celkovém počtu vybavených slov a pamět'ový výkon u dětí s věkem vzrůstá od 9 do přibližně 12 let. Dále autor doporučuje výsledky brát spíše informativně, jelikož všechny děti ze studie pochází z Prahy a oproti běžné populaci bylo ve vzorku jejich rodičů $3 \mathrm{x}$ častěji zastoupeno vysokoškolské vzdělání. Preiss a kolegové provedli v roce 2001 rozšíření této studie na vzorek 550 dětí (Preiss, Motejlková, Janů, \& Kolárová). Pro adolescenty a dospělé jsou normy v manuálu pouze orientační, jelikož jsou převzaty ze zahraničních studií. Zde je velká paleta různě věkově odstupňovaných norem až do 87 let, pro muže a ženy zvlášt' i dohromady, pro zdravou populaci i specifické populace pacientů. Za nejkvalitnější autor považuje metaanalýzu osmi studií z let 1980 - 2003 provedenou na 1910 zdravých osobách ve věku 20-79 let (Mitrushina, Boone, Razani, \& D‘Elia, 2005) publikovanou v manuálu z roku 2013. Autor nepopisuje žádný postup jak vybrat nejkvalitnější orientační normu; je zde tedy ponechán prostor úsudku administrátora testu. Ačkoliv normy pro dospělé jsou pouze orientační, M. Preiss píše, že výsledky české populace $v$ PTU jsou téměř shodné s americkými i švýcarskými normami, což ukazuje na studii žáků středních škol, a tedy orientační normy lze brát poměrně vážně. Oproti manuálu byla $\mathrm{v}$ roce 2014 vydaná česká studie reportující normy pro zdravou populaci mezi 20 a 85 lety (Bezdicek et al.). Autoři (mimo jiné i M. Preiss, autor PTU) studii prováděli na 306 respondentech (182 žen, 124 mužů) a zahrnuli do analýzy všech 8 aspektů PTU i vliv věku, pohlaví a délky studia.

\section{Validita}

\begin{tabular}{|c|c|c|}
\hline 2.10 & $\begin{array}{l}\text { Celková adekvátnost: (Tento celkový rating se získá na základě posouzení hodnot ratingů } \\
\text { daných v položkách } 2.10 .1-2.10 .2 .4 \text {. Neprůměrujte pouze čísla, abyste získali celkový rating. } \\
\text { Obvykle bude roven bud' konstruktové validitě nebo validitě vztahující se ke kritériu, podle } \\
\text { toho, která z nich je vyšší.) }\end{array}$ & 3 \\
\hline 2.10 .1 & $\begin{array}{l}\text { Konstruktová validita - celková adekvátnost } \\
\text { (Tento celkový rating se získá na základě posouzení hodnot ratingů daných v položkách } \\
\text { 2.10.1.2 - 2.10.1.6. Neprúměrujte pouze čísla, abyste tento celkový rating získali.) }\end{array}$ & 3 \\
\hline 2.10 .1 .1 & 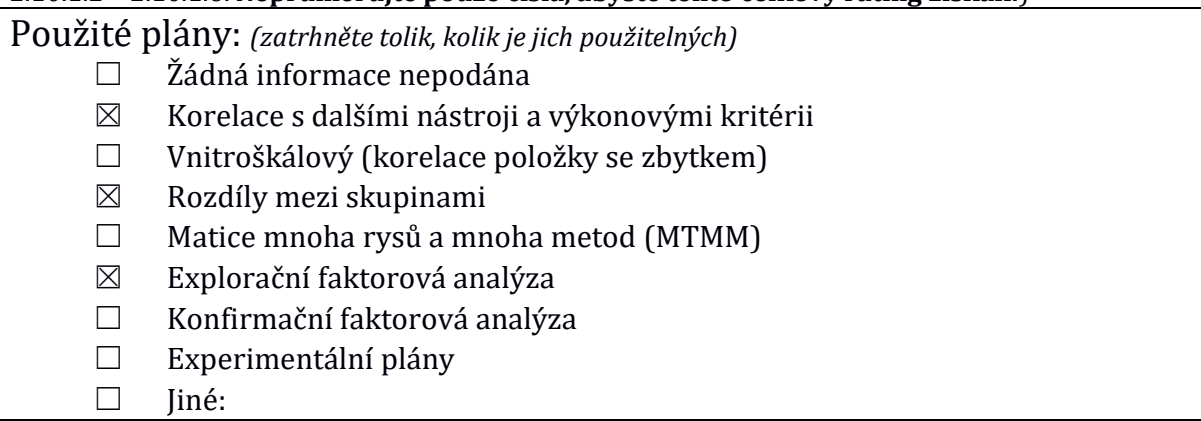 & \\
\hline 2.10 .1 .2 & $\begin{array}{cl}\text { Velikosti výběrů: } \\
0 & \text { Žádná informace neposkytnuta. } \\
1 & \text { Jedna neadekvátní studie (např. velikost výběru menší než 100). } \\
3 & \text { Jedna adekvátní studie (např. velikost výběru 100-200). } \\
4 & \text { Více než jedna adekvátní nebo velká studie. } \\
5 & \text { Dobrá série adekvátních až rozsáhlých studií. } \\
\end{array}$ & 5 \\
\hline 2.10 .1 .3 & $\begin{aligned} \text { Procedura výběru souboru: } \\
\quad \square \quad \text { Žadná informace neposkytnuta } \\
\square \quad \text { Reprezentativní vǔči populaci [sumarizujte kritéria] } \\
\square \quad \text { Nahodilá } \\
\square \quad \text { Náhodná }\end{aligned}$ & \\
\hline 2.10 .1 .4 & $\begin{array}{cl}\text { Medián a rozsah korelací mezi testem a dalšími podobnými testy: } \\
0 & \text { Žádná informace neposkytnuta. } \\
1 & \text { Neadekvátní }(\mathrm{r}<0.55) . \\
3 & \text { Adekvátní }(0.55<\mathrm{r}<0.65) . \\
4 & \text { Dobrý }(0.65<\mathrm{r}<0.75) . \\
5 & \text { Vynikající }(\mathrm{r}>0.75) \\
\end{array}$ & 1 \\
\hline
\end{tabular}




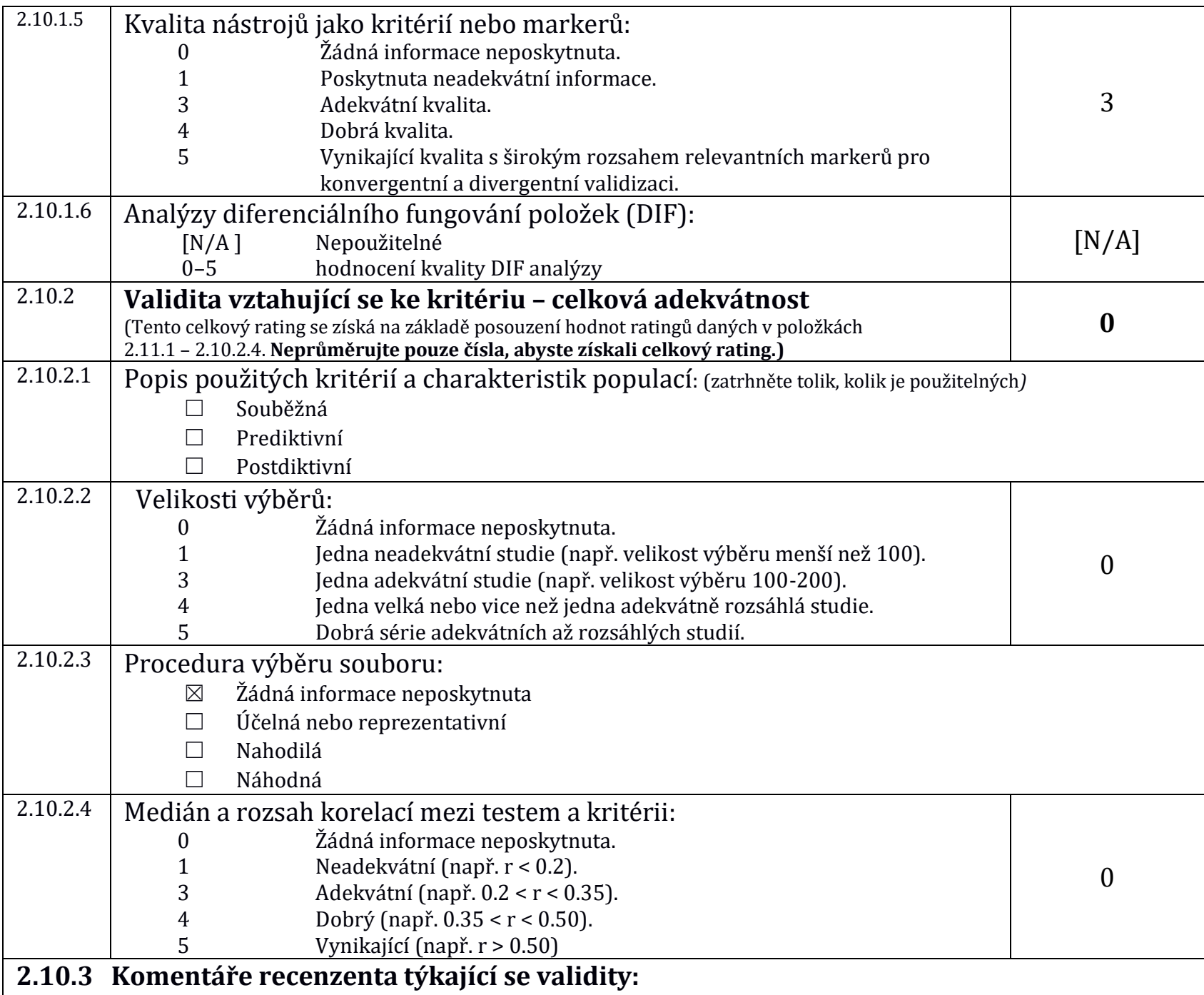

Popisu validity, resp. jejích důkazů není v manuálu věnováno mnoho pozornosti. Pokud jde o konstruktovou validitu, důkazy se omezují na korelaci výkonu v PTU s věkem a s IQ. Na vzorku psychiatrických pacientů $(\mathrm{N}=47)$ byla zjištěna korelace $-0,37$ mezi věkem a celkovým výkonem $v$ testu (na 5\% hladině významnosti). Čím vyšší byl věk participantů, tím horší byl výkon v testu. U dětí $(\mathrm{N}=182)$ s rostoucím věkem $v$ pásmu 9-14 let naopak pamět'ový výkon vzrůstal $(\mathrm{r}=0,34)$, mezi 12.-14. rokem však již jen minimálně. Počet opakování s věkem klesal $(\mathrm{r}=-0,16)$, ale počet konfabulací nikoliv $(\mathrm{r}=0,02)$. Tyto výsledky odpovídají teoretickým informacím o paměti, jelikož výsledky v pamět'ových testech by se $\mathrm{v}$ dětství měly zlepšovat, $\mathrm{v}$ dospělosti být poměrně ustálené a ve stáří se opět zhoršovat. Korelace $s$ inteligencí jsou v dětském souboru nízké, pro celkové IQ 0,21, pro verbální i názorové 0,18. Tuto skutečnost lze chápat jako důkaz o divergentní validitě. Jinak řečeno, na základě hodnot korelací lze říci, že PTU měří něco jiného než inteligenci.

Popis konvergentní validity chybí úplně, stejně tak popis prediktivní validity a dalších aspektů validity. Zároveň je nutno dodat, že zahraniční literatura tuto část zpracovává obsáhleji a poskytuje tak potřebné důkazy o validitě, které $\mathrm{v}$ manuálu českého vydání chybí. Napřr. Ryan, Rosenberg a Mittenberg (1984) podávají informace o faktorové validitě. Neurologickým pacientům $(\mathrm{N}=108)$ dali $\mathrm{k}$ vyplnění PTU, 3 WAIS verbální a 3 výkonové subtesty, WMS subtesty mentální kontroly, počítání (Digit Span), párového asociačního učení, logické paměti a vizuální reprodukce a všechny odpovědi podrobili faktorové analýze. Ta odhalila př́tomnost čtyř faktorů vysvětlujících dohromady 75,4\% rozptylu. PTU, párové asociace a logická pamět' zformovaly první faktor a významně se tím odlišily od testů měřících verbální a neverbální inteligenci a pozornost. Konvergentní a divergentní validitu zkoumali de Sousa Magalhães, Fernandes Malloy-Diniz a Cavalheiro Hamdan (2012) pomocí série korelací mezi PTU a různými dalšími testy na 34 zdravých participantech. Konvergentní validita $(r=0,37-0,44)$ byla nalezena mezi testy PTU a Benton Visual Retention Test (BVRT), zatímco na divergentní validitu ukazuje nesignifikantní korelace mezi PTU a Trail Making Test (TMT). Další důkazy o konvergentní 


\section{Reliabilita}

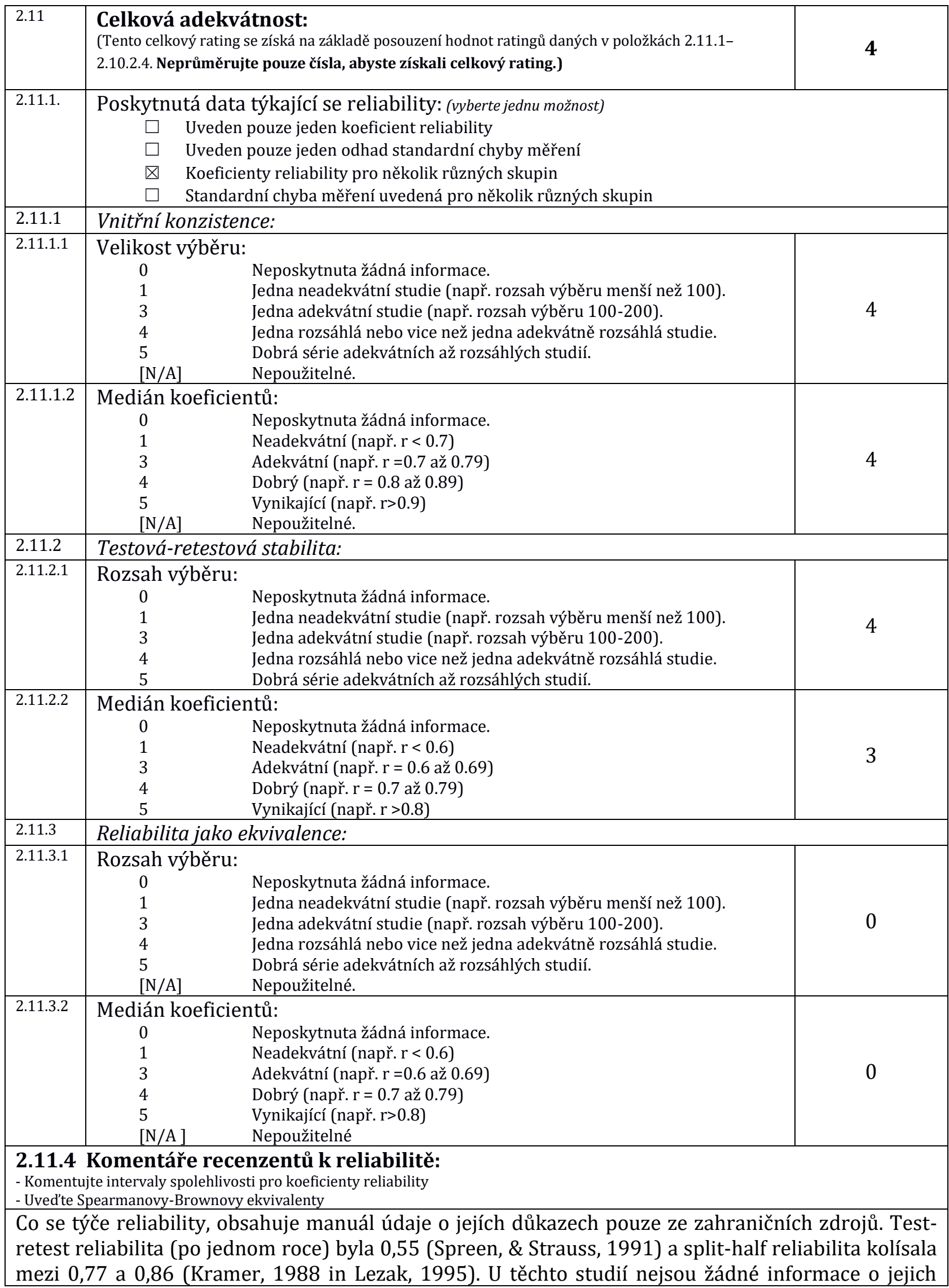


probandech. Z dalších zahraničních prací bych zmínila reliabilitu paralelních forem testu měřenou na 85 klinických pacientech (prům. věk=45,86 let), která se pohybuje mezi 0,60 a 0,77 (Ryan, Geisser, Randall, \& Georgemiller, 1986) a opět měření test-retest reliability po 3 měsících na vzorku 225 dětí (6-12 let) s výsledkem 0,70 či 0,59 po započtení vlivu věku dítěte (van den Burg, \& Kingma, 1999).

Č́ást 9:

Závěrečné hodnocení:

3.0 Hodnotící zpráva testu:

Tato část by měla obsahovat stručné, jasně obhájené posouzení nástroje/produktu. Mělo by popisovat jeho pro a proti a poskytnout určitá obecná doporučení týkající se toho, jak a kdy by se měl používat - spolu s varováními (kde jsou potřebná) týkajícími se případů, kde by se používat neměl.

Pamětový test učení představuje jednu z nejpoužívanějších metod určenou k měření různých aspektů paměti využitelnou v řadě oblastí aplikované psychologie. Tato skutečnost spolu s jednoduchostí a rychlostí administrace PTU patří mezi klady metody.

České vydání nicméně trpí některými nedostatky. Předně jsou české normy v manuálu dostupné pouze pro děti ve věku 9-14 let a pro zbylou populaci jsou normy orientační, převzaté ze zahraničí. Tyto normy se liší v mnoha parametrech (věk, pohlaví, množství zahrnutých aspektů testu apod.) a je tedy poměrně obtížné posoudit jejich kvalitu a vybrat normu pro interpretaci výsledků konkrétního probanda. Autor pro tento výběr nezmiňuje žádný postup. Fakt, že již 4 roky existují normy pro českou populaci ve věku 20-85 let zatím v manuálu není reflektován, jelikož od vydání v roce 1999 nedošlo k jeho oficiálnímu přepracování.

Další nevýhodou je neuspokojivý popis důkazů o validitě a reliabilitě, které sice lze najít v zahraniční literatuře, nicméně tyto zdroje nemusí být pro běžného uživatele testu dobře dostupné

\subsection{Závěry:}

I přes některé nedostatky bych test určitě doporučila $\mathbf{k}$ použití. Důkazy o validitě a reliabilitě jsou velmi podstatné, nicméně $s$ vynaložením určitého úsilí jsou dohledatelné a mohou tedy být dostupné i externě. Ačkoliv autor nezmiňuje postup výběru norem pro dospělou populaci, samotnou interpretaci výsledků popisuje kvalitně a nové české normy k dispozici jsou, takže testování české populace dle norem nic zásadního nebrání. Bylo by vhodné vypracovat nový manuál zahrnující již výsledky práce Bezdíčka a jeho kolegů, do té doby se díky množství kvalitních zahraničních studií dá $s$ testem pracovat za použití externích norem. Uživatel si dokonce ani nemusí kupovat poměrně drahý manuál, nebot' je na trhu volně prodejná kniha (Preiss, Bartoš, \& Čermáková, 2013) s celým manuálem a záznamovým archem PTU (dostupná již od 85 Kč) a s dalšími testy jako bonus k tomu. Pro použití v praxi je však každopádně nezbytné, aby si český psycholog samostatně vyhledal adekvátní normy vždy pro dané použití. 


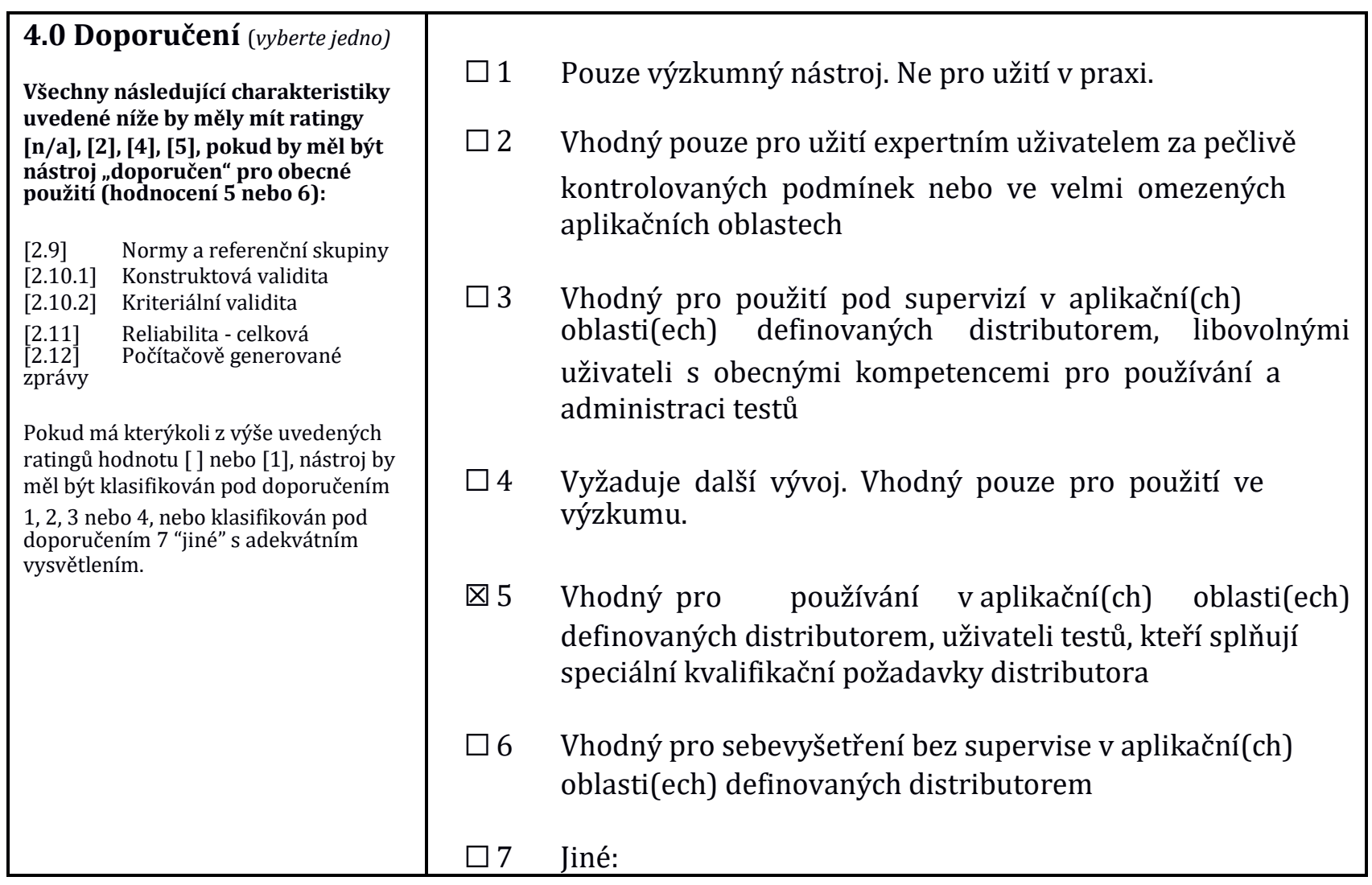

\section{Odkazy k poznámkám a bibliografie}

Bezdicek, O., Stepankova, H., Moták, L., Axelrod, B. N., Woodard, J. L., Preiss, M., ... \& Poreh, A. (2014). Czech version of Rey Auditory Verbal Learning test: normative data. Aging, Neuropsychology, and Cognition, 21(6), 693-721. doi:10.1080/13825585.2013.865699

Crossen, J. R., \& Wiens, A. N. (1994). Comparison of the Auditory-Verbal Learning Test (AVLT) and California Verbal Learning Test (CVLT) in a sample of normal subjects. Journal of Clinical and Experimental Neuropsychology, 16, 190-194. doi:10.1080/01688639408402630

de Sousa Magalhães, S., Fernandes Malloy-Diniz, L., \& Cavalheiro Hamdan, A. (2012). Validity Convergent and Reliability Test-retest of the Rey Auditory Verbal Learning Test. Clinical Neuropsychiatry, 9(3), 129-137. Retrieved from:

http://www.clinicalneuropsychiatry.org/pdf/03\%20magalhaes.pdf

Delis, D. C., Kramer, J. H., Kaplan, E., \& Thompkins, B. A. O. (1987). CVLT: California verbal learning test-adult version: manual. San Antonio: Psychological Corporation.

Edwards, H. F. (1988). A comparison of the Rey Auditory-Verbal Learning Test with the California Verbal Learning Test. Amedd Clinical Psychology Short Course, 90, 90-99. Retrieved from: http://www.dtic.mil/dtic/tr/fulltext/u2/a227854.pdf\#page=100

Jafari, Z., Steffen Moritz, P., Zandi, T., Aliakbari Kamrani, A., \& Malyeri, S. (2010). Psychometric properties of Persian version of the Rey Auditory-Verbal Learning Test (RAVLT) among the elderly. Iranian Journal of Psychiatry and Clinical Psychology, 16(1), 56-64.

Lemay, S., Bédard, M. A., Rouleau, I., \& Tremblay, P. L. (2004). Practice effect and test-retest reliability of attentional and executive tests in middle-aged to elderly subjects. The Clinical Neuropsychologist, 18, 284-302. doi:10.1080/13854040490501718

Lezak, M. (1995). Neuropsychological Assesment. New York: Oxford University Press.

Malloy-Diniz, L. F., Lasmar, V. A. P., Gazinelli, L. D. S. R., Fuentes, D., \& Salgado, J. V. (2007).

The Rey auditory-verbal learning test: applicability for the Brazilian elderly population. Revista Brasileira de Psiquiatria, 29, 324-329. doi:10.1590/S151644462006005000053

Mitrushina, M., Boone, K.B., Razani, J., \& D`Elia, L.F. (2005). Handbook of Normative Data for Neuropsychological Assessment. New York: Oxford University Press. 
Preiss, M. (1994). Pamět'ový test učení pro klinickou praxi. Československá psychologie, 38, 257-265.

Preiss, M. (1998). Pamětový test učení: metodický manuál IPPP ČR. Brno: Psychodiagnostika.

Preiss, M. (1999). Pamětový test učení: manuál pro dospělé a děti. Brno: Psychodiagnostika.

Preiss, M., Bartoš, A. \& Čermáková, R. (2013). Neuropsychologická baterie Psychiatrického centra Praha, 3. vydání. Praha: Psychiatrické centrum.

Preiss, M., Motejlková, J., Janů, I., \& Kolárová, E. (2001). Pamět’ový test učení: současné normy pro děti ve věku 9-14 let. Retrieved from: http://docplayer.cz/13455808-Pametovy-test-uceni-soucasnenormy-pro-deti-ve-veku-9-14-let.html

Ryan, J. J., Geisser, M. E., Randall, D. M., \& Georgemiller, R. J. (1986). Alternate form reliability and equivalency of the Rey Auditory Verbal Learning Test. Journal of Clinical and Experimental Neuropsychology, 8(5), 611-616. doi:10.1080/01688638608405179

Ryan, J., Rosenberg, J.S., \& Mittenberg, W. (1984). Factor analysis of the Rey Auditory-Verbal Learning Test. International Journal of Clinical Neuropsychology, 6(4), 239-241.

Spreen, O., \& Strauss, E. (1991). A compedium of neuropsychological tests. New York: Oxford University Press.

van den Burg, W., \& Kingma, A. (1999). Performance of 225 Dutch school children on Rey's Auditory Verbal Learning Test (AVLT): parallel test-retest reliabilities with an interval of 3 months and normative data. Archives of Clinical Neuropsychology, 14(6), 545-559. doi:10.1016/S08876177(98)00042-0

\section{Měřené konstrukty:}

Bezprostřední a krátkodobá verbální pamět', proces učení. 